\title{
As representações do rio Tibagi, Paraná - Brasil, e 0 abastecimento de água potável na cidade de Londrina (1970-1990)
}

\section{Representations of the Tibagi River (Paraná - Brazil) and drinking water supplies in the city of Londrina (1970-1990)}

\author{
Gilmar Arruda \\ Universidade Estadual de Londrina (UEL) \\ arruda@sercomtel.com.br \\ Londrina \\ Brasil \\ Eliane Aparecida Biasetto \\ Universidade Estadual de Londrina (UEL) \\ Londrina \\ Brasil
}

Recibido: 13 de marzo de 2015

Aprobado: 11 de agosto de 2015

\section{RESUMO}

Nos anos de 1970, na cidade de Londrina-Paraná, Brasil, a grande expansão populacional intensificou problemas sociais urbanos como a falta de água potável. Havia duas propostas para resolver o problema: a primeira era a captação das águas do Aquífero Guarani, à época denominado Botucatu; a outra era a captação das águas do rio Tibagi. Entre o início dos anos de 1970 e meados da década de 1980, quando foi escolhida a opção pelo rio, emergiu e se propagou a representação da poluição do rio Tibagi. Nesse artigo, investigamos o surgimento, a circulação, as características dessa representação e quais os atores sociais que se utilizaram dela em suas estratégias de ação. Utilizamos como fontes as matérias dos jornais locais como a "Folha de Londrina", e depoimentos de duas lideranças dos movimentos contrários ao projeto Tibagi: 0 engenheiro agrônomo Marcos Castanheira e o engenheiro civil Nelson Amanthea.

\section{PaLAVRAS-ChaVe}

Abastecimento de água, Londrina (cidade do Brasil), poluição, rio Tibagi.

\section{ABSTRACT}

The great population expanse in the 1970 decade has intensified urban social problems in the city of Londrina (Paraná, Brazil) such as the lack of potable water. Two proposals could solve the matter: first, to collect water from the Guarani Aquifer, named Botucatu at the time; on the other hand, water could be collected from the Tibagi River. The river was chosen as supply between the early 1970's and the middle 1980's, which emerged and propagated the representation of pollution on the Tibagi River: In this article, we investigate the awakening, circulation, features, and social agents making use of this representation in their plans of action. Sources such as local newspaper stories from "Folha de Londrina" were used, as well as testimonials from two leaders of movements contrary to the Tibagi Project: agronomist engineer Marcos Castanheira and civil engineer Nelson Amanthea.

\section{KEYWORDS}

Water supply, Londrina (Brazilian city), polution, Tibagi River. 


\section{Os rios, os homens e a historiografia}

A historiografia brasileira tem dado pouca atenção aos rios e sua história. Embora raramente apareçam, os rios não estão ausentes na historiografia. Eles são encontrados em análises dos historiadores do século XIX e início do XX, como Capistrano de Abreu, historiador brasileiro das primeiras décadas do século XX. Os rios aparecem inseridos nas suas preocupações com os problemas de interiorização da "civilização" e com as definições dos limites territoriais. Nessa perspectiva encontramos os rios São Francisco, o Amazonas, o Paraguai, etc. 0 rio Tietê, que corta 0 Estado de São Paulo, no sentido leste oeste, por exemplo, ainda nos anos 40 do século XX, foi objeto de um estudo de Humberto Mello Nobrega, História do Rio Tietê (1981), que o transformou numa estrada do "expansionismo paulista". Sérgio Buarque de Holanda, já quase em meados do século XX, com seus estudos sobre às monções, atualizou os significados dos rios, chamando-os de rios que caminham, importantíssimos no processo de "devassamento dos sertões".

Mais recentemente, motivado, em parte, pelas novas e urgentes demandas pela água doce, ${ }^{1}$ pela geração de energia elétrica, ${ }^{2}$ pelo crescimento do movimento ambientalista ${ }^{3}$ e pelo campo da história ambiental ${ }^{4}$ surgiram algumas pesquisas tematizando os cursos d'água abordando-os a partir de variados enfoques. Em outros países existe uma tradição já antiga de pesquisa sobre os rios e, em particular, encontra-se pesquisas sobre os rios inseridas dentro do campo da história ambiental. Autores como Richard White, em The organic machine, ${ }^{5}$ que realizou um dos estudos mais sugestivos para a história ambiental dos rios, analisando o rio Columbia em suas diversas dimensões, a partir do início do século XIX, quando aparecem os primeiros relatos de brancos sobre aquele rio. Para White, os rios são uma "máquina orgânica", um "sistema de energia" que, embora modificado pelos humanos, mantem-se natural, com suas qualidades "não fabricadas".

0 embate característico da era da eletricidade, peixe versus barragens, foi estudado por Matthew D. Evenden, que tomou como objeto o rio Fraser, no Canadá. ${ }^{6}$ A motivação de Evenden para estudar os rios foi que, segundo ele, ao longo do século XX os humanos transformaram os rios em todos os locais do planeta, com exceção da Antarctica, barrando-0s, desviando suas correntezas, degradando-0s. ${ }^{7}$ Nas palavras do autor, o livro Fish versus Power, "narra a crônica de um rio, o qual na era do desenvolvimento industrial moderno, consumidora de todas os suprimentos de energia, não seguiu a trajetória conhecida. Em uma era quando extensas barragens estão sendo colocadas sob intensas críticas, o caso do rio Fraser pode nos lembrar como é precária a defesa do meio ambiente. ${ }^{8}$

Mas não são apenas as demandas por salmões e eletricidade que podem ser estudadas ou que influenciam as relações entre os humanos e o meio ambiente de um rio. 0 livro River flowing from the sunrise de James M. Anton e Robert S. McPherson, ${ }^{9}$ sobre a parte baixa do rio San Juan, nos mostra outros aspectos e nuances para se analisar um rio do ponto de vista da história ambiental. Com populações diversas, comanches, apaches, mórmons, não mórmons, mexicanos ocupando suas margens e disputando suas águas, margens e recursos ao longo do tempo, o rio San Juan, significou uma oportunidade de "estudo de caso da forma como as culturas lidaram uma com as outras no seu desenvolvimento, no caldeirão da cooperação, coexistência e conflitos. Poucas histórias de rios abrem tantas diferentes janelas para se ver as relações de raça e meio ambiente."10

No Brasil, alguns estudos sobre os rios têm sido realizados nas últimas décadas, não necessariamente associados ao campo da história ambiental. A relação rios e territórios, que já tinha aparecido em estudos clássicos, como os de Sergio Buarque de Holanda, mencionados anteriormente, é um aspecto central em alguns

\footnotetext{
1 Rebouças, Aldo. "0 ambiente brasileiro: 500 anos de exploração - os recursos hídricos". In Patrimônio Ambiental Brasileiro, editado por Wagner C. Ribeiro, 191 -233. Paulo: Edusp, 2003

2 Bermann, Célio. "Energia, patrimônio sustentável e sustentabilidade no Brasil." In Patrimônio Ambiental Brasileiro, editado por Wagner C. Ribeiro, 243-281. São Paulo: Edusp, 2004

${ }^{3}$ Jacobi, Pedro. "Movimento ambientalista no Brasil: representação social e complexidade da articulação de práticas coletivas." In Patrimônio ambiental brasileiro, editado por Wagner C. Ribeiro, 519-545. São Paulo: Edusp, 2004.

${ }^{4}$ Duarte, Regina H. "Por um pensamento ambiental histórico: 0 caso do Brasil,. Luzo-Brazilian Review 41,2 (2005): 144-161.

${ }^{5}$ White, Richard. The organic machine: the remaking of the Columbia River. New York: Hill and Wang, 1995.

${ }^{6}$ Evenden, Matthew D. Fish versus Power: an environmental history of the Fraser River. New York, University Cambridge Press, 2004.

${ }^{7}$ Eevenden, Fish versus power,2004.

${ }^{8}$ Evenden, Fish versus power, 17.

9 Anton, James, Robert McPherson. River flowing from the Sunrise an environmental history of the Lower San Juan. Logan: Utah State University Press, 2000

${ }^{10}$ Anton, McPherson, River flowing from the sunrise, 3.
} 
desses novos estudos. 0 estudo de Haruf Salmen Espíndola, Sertão do rio Doce ${ }^{11}$ pode ser enquadrado nessa nova onda de estudos. 0 autor demonstra concretamente como o processo de "mundialização" dos territórios afetaram e influenciaram políticas e ações concretas por parte dos governos provinciais e centrais em relação ao rio Doce, no período entre 1800 e 1845. As iniciativas e projetos analisados pelo autor almejavam facilitar 0 acesso do interior do país, a província de Minas Gerais, ao mercado mundial através de "um canal fluvial" e também visavam " a incorporação de território de floresta e a guerra aos índios" e ocuparam espaço significativo na pauta do governo central e dos governos de Minas Gerais e do Espírito Santo. 0 objetivo principal de Espindola foi analisar a "guerra de conquista movida pela Coroa Portuguesa e, depois, pelo Império do Brasil, objetivando fazer do rio Doce um canal de ligação com um porto de mar e integrar a economia de Minas ao mercado mundial."12

A incorporação dos territórios interiores do país, muito pouco conhecidos pelo governo central e também pelos governos provinciais desencadearam iniciativas de mapeamento, estudos, instalação de colônias militares, a política de aldeamento indígena. Em muitos casos, os vales dos grandes rios assumiram um papel fundamental nas estratégias de governantes para a construção e afirmação da territorialidade estatal, como é o caso do rio Doce: "é uma categoria central para a história de Minas Gerais, pois, muito mais que um rio, é território, paisagem, lugar, representação."13

Entretanto, deve-se destacar, como um dos estudos pioneiros aproximando História Social e História Ambiental, o estudo de Victor Leonardi, Os historiadores e os rios,14 que foi definido como "...um ensaio historiográfico, que trata, portanto, da história social e ambiental do baixo rio Negro e de alguns de seus afluentes da margem direita."15 Não é um tema fácil pois se trata de estudar o desaparecimento, a "morte" de uma cidade, de uma localidade, de uma comunidade em cuja a história desde o século XVI até o seu completo desaparecimento na década de 1960, esteve imersa em intensas e diferentes relações estabelecidas com o seu meio, os rios da Amazônia. Diz Leonardi: "Como caracterizar esses complexos processos históricos que abarcaram, contraditoriamente, estratégias de luta pela sobrevivência na floresta e, ao mesmo tempo, profundas e sucessivas crises, inclusive a crise maior, a do fim definitivo da própria povoação?"16

Nessa linha de estudos, na década seguinte apareceu o estudo de Janes Jorge, Tietê: o rio que a cidade perdeu. ${ }^{17} 0$ autor define sua pesquisa como estando na intersecção entre a história social do cotidiano e a história ambiental ou ecológica: "Assim, ao lado da história social do cotidiano, foi preciso dialogar com a história ambiental e ecológica..." 18 Seus objetivos "...eram recuperar o Tietê no cotidiano dos moradores de São Paulo, entender de que forma os processos relacionados à urbanização paulista degradaram o principal rio da cidade e identificar os impactos socioambientais daí decorrentes entre os anos de 1890 e 1940." 19 Janes Jorge nos mostra os atores sociais, o cotidiano, as práticas de relacionamento com um rio e como as transformações decorrentes da "era da revolução tecno-científica" com o surgimento de novas tecnologias e 0 aparecimento das metrópoles. Esse processo de expansão da sociedade capitalista por todas as partes do mundo, a expansão da modernidade, no dizer de Foot Hardman, impactou de diferentes formas espaços geográficos diferénciados.

A historiografia comentada anteriormente indica alguns caminhos e perspectivas para tomar os rios como objeto de estudo no campo da história ambiental, quer seja em outros campos da história, como a história social. Nesse artigo, o objeto de análise é o rio Tibagi, no estado do Paraná, sul do Brasil. 0 rio Tibagi, é o principal afluente da margem esquerda do rio Paranapanema, estando sua bacia inteiramente contida no estado do Paraná, fazendo parte da grande bacia do rio Paraná, um dos formadores da bacia do rio da Prata. Nasce entre os municípios de Ponta Grossa e Palmeira, sul do Estado, a uma altitude aproximada de 1.100 metros e percorre cerca de 600 quilômetros até sua foz no nos municípios de Sertaneja e Primeiro de Maio, a uma altitude

\footnotetext{
${ }^{11}$ Espíndola, Haruf S. Sertão do rio Doce. Bauru: Edusc/Governador Vạladares: Editora Univale, 2005.

${ }^{12}$ Espíndola, Sertão do rio Doce, 25.

${ }^{13}$ Espíndola, Sertão do rio Doce, 26.

14 Leonardi, Victor. Os historiadores e os rios: natureza e ruína na Amazônia brasileira. Brasília: Editora UnB/Paralelo 15, 1999. A pesquisa foi originalmente uma contribuição historiográfica para um plano de manejo do Parque Nacional do Jaú em 1996. 0 parque foi criado em 1980, englobando 0 rio e seus afluentes em um total de 2.272 .000 hectares.

${ }^{15}$ Leonardi, Os historiadores e os rios, 19. Leonardi realiza nesse ensaio a aproximação entre a história ambiental e a social, não se esquecendo de enfrentar a discussão com a história econômica, mas ao mesmo tempo rejeitando o reducionismo economicista. Na década seguinte essa tarefa metodológica seria proposta por Stephen Mosley. Ver Mosley, Stephen. "Common ground: integrated social and environmental history." Journal of Social History 39, 3 (2006): $915-933$.

${ }^{16}$ Leonardi, Os historiadores e os rios, 20.

${ }^{17}$ Jorge, Janes. Tietê, o rio que a cidade perdeu. São Paulo, 1890-1940. São Paulo: Alameda, 2006.

18 Jorge, Tietê..., 16-17.

${ }^{19}$ Jorge, Tietê..., 19.
} 
aproximada de 300 metros. 0 rio Tibagi possui 65 tributários principais com uma área de drenagem de pouco mais de $25.000 \mathrm{~km}^{2}$, apresentando em seu curso 91 cachoeiras e corredeiras com alguns saltos destacados, como os de Peludo, com 5 metros, 0 de Grande Conceição com 115, 5 metros, 0 de Mauá, com 28 metros. ${ }^{20}$

A bacia do rio Tibagi atravessa três planaltos que influenciam diretamente nas suas características físicas. 0 alto Tibagi, no Primeiro Planalto, em suas cabeceiras, apresenta uma forte declividade e uma sucessão de espigões e vales profundos em forma de "V". 0 médio Tibagi, no Segundo Planalto, caracteriza-se por relevos tabulares em forma de "cuestas" e plataformas dissecadas. Os solos são pouco profundos e apresentam baixa fertilidade. Já no Terceiro Planalto, no baixo Tibagi caracteriza-se por ser uma região de rochas eruptivas básicas da Formação Serra Geral, com solos férteis e relevos suaves e ondulados. ${ }^{21}$

É, segundo Valmir de França, um rio com características do "padrão de drenagem das bacias hidrográficas paranaenses, suas águas vão para o interior, para oeste, até encontrar o rio Paraná, diretamente ou através do Paranapanema. 0 atuâl padrão de drenagem teve sua gênese a partir do Terciário Inferior, quando acompanhou a inclinação local e a inclinação geral da superfície topográfica, resultantes das condições tectônicas."22

0 estudo de um rio, em quaisquer circunstâncias, no campo da história deve tomar como ponto de partida 0 que Lucien Febvre ${ }^{23}$ designou como as 'funções' que os humanos atribuíram a determinado rio ao longo de suas relações com esse elemento natural. Entende-se que a história e, em particular, a história ambiental, interessa-se pelas relações entre os humanos e a natureza, seus mútuos condicionamentos ao longo do tempo. ${ }^{24}$

Nesse sentido, a escolha do rio Tibagi, em particular o enfoque escolhido nesse texto, precisa de alguns esclarecimentos sobre a coevolução dos humanos com o curso de água. Deve-se considerar que ocorreram transformações na bacia hidrográfica do rio Tibagi antes da chegada dos humanos e que elas continuariam a ocorrer, com ou sem a presença desta espécie. Existem inúmeros fatores e processos naturais que estão fora do alcance direto e imediato das ações intencionais ou não dos humanos e suas sociedades, ou que pelo menos estavam fora de alcance, segundo alguns cientistas. ${ }^{25}$ As correntezas de um rio, 0 seu ritmo, volume, cheias e secas, surgiram antes do aparecimento da espécie humana e continuaram existindo após a sua aparição, por um largo período, sem que as sociedades conseguissem manejá-las. Até bem recentemente, na bacia do rio Tibagi, a espécie humana aproveitava-se de suas características naturais, como utilizar a correnteza para a navegação. Às vezes, as suas características impediam que se utilizasse do rio, por algum tempo. As enchentes e vazantes do rio Tibagi em vários momentos fizeram com que os humanos alterassem os seus planos de navegação ou tivessem que procurar outros lugares para buscar recursos de sobrevivência. Com a emergência da 'era antropocena', esta relação começou a pender para o lado dos humanos, embora existam notícias de barragens, canais e desvios de água datados de 8.000 anos A. P. na região da Mesopotâmia e na América. ${ }^{26}$

Além das categorias de tempo histórico e biológico, cuja combinação representa um desafio para a história ambiental, a definição de marcos significativos envolve as referências espaciais nos quais eles seriam válidos, ou operacionais. Um primeiro problema seria a abrangência da referência espacial. Tomemos inicialmente o conceito

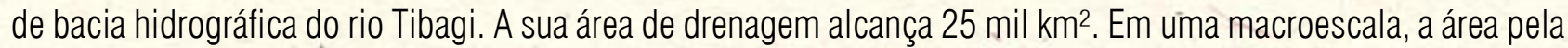
qual o rio Tibagi corre está inserida no domínio natural da Mata Atlântica, com interseções de floresta de araucárias, campos, etc. Não há uma formação natural predominante em toda a sua extensão. As formações geológica e de relevo, as configurações paisagísticas, de flora e fauna também são diversas. Nesse sentido não se encontra uma homogeneidade espacial/natural que serviria de delimitação para a análise dos processos históricos no espaço da bacia. Não se trata, portanto, de se encontrar marcos significativos das relações das sociedades com um determinado bioma ou ecossistema.

\footnotetext{
${ }^{20}$ França, Valmir de. "0 rio Tibagi no contexto hidrológico paranaenșe." In A bacia do rio Tibagi, editado por Medri, M Bianchini, E. Shibata e José Pimenta, 45-63. $A$ bacia do Rio Tibagi. Londrina: Medri, 2002.

${ }^{21}$ Estado do Paraná, SUDERHSA. Plano da bacia hidrográfica do rio tibagi módulo / -diagnóstico. Minuta em 15 de abril de 2008. Curitiba. SEMA, 2008.

${ }^{22}$ França, "O rio Tibagi no contexto hidrológico paranaense", 47.

${ }^{23}$ Febvre, Lucien. O reno, mitos e realidades. Rio de Janeiro: Civilização Brasileira, 2000.

${ }^{24}$ Worster, Donald. "Para fazer história ambiental," Estudos Históricos 4, 8 (1991): 198-215; Drummond, José A. "Por que estudar a história ambiental no Brasil? Ensaio temático." Varia História 26 (2002); Pádua, José A. "As bases teóricas da história ambiental." Estudos Avançados 24, 68 (2010).

${ }^{25}$ Em setembro do ano de 2009, Johan Rockström e outros 26 cientistas de diversas especialidades, países e instituições de pesquisa publicaram um artigo, quase como um manifesto, alertando para os limites da ação humana na Terra. Ver: Rockström, J. et al. "A safe operating space for humanity." Nature 461, 24 (2009).

${ }^{26}$ World Comission on Dams (WCD). United Nations. Dams and development. A new framework for decision-making. The Report of the World Commission on Dams. London: Earthscan Publications, 2000, e Anton, James M., Robert S. McPherson, River Flowing from the Sunrise: an environmental history of the Lower San Juan. Logan: Utah State University Press, 2000.
} 
A escolha da delimitação espacial nesse estudo baseou-se nas territorialidades constituídas no processo concreto da presença dos humanos na bacia hidrográfica. Esses territórios e territorialidades aparecem em formas simbólicas e concretas de apropriação do espaço natural: os conhecimentos adquiridos pela vivência ou pelas ciências; as formas e produtos utilizados, apropriados ou introduzidos para a sobrevivência ou para outros fins (comércio); os artefatos e materiais usados e construídos na apropriação dos bens naturais (madeira ou ferro); as formas de estabelecimento de limites dos territórios (relevo, paisagem ou coordenadas geográficas); os meios e tecnologias usados para a circulação pelo território (correnteza, veredas, estradas, ferrovias); as formas simbólicas de representação desses territórios e territorialidades. Ressalva-se que o foco do estudo, levado a cabo nesse artigo, refere-se às territorialidades constituídas pelas populações de origem europeia, que se instalaram na bacia a partir do início do século XVII.

Até 0 início do século XVIII, era limitada a presença permanente, na bacia do rio Tibagi, dos europeus e seus descendentes, assim como de africanos escravizados introduzidos no Brasil pela metrópole. Esses grupos humanos já se encontravam estabelecidos no litoral, na região da baía de Paranaguá; no primeiro planalto, onde hoje se encontra Curitiba e com alguma presença esporádica nas cabeceiras dos afluentes do rio. Nas florestas e campos que cobriam a margem oeste do rio a presença daquelas populações era ainda mais escassa e se limitava às margens dos rios, especialmente nas reduções jesuíticas ao longo do rio Ivaí e nas margens do rio Paranapanema. Poúquíssimos elementos da biota do 'velho mundo' haviam chegado até estes domínios. Os bovinos, equinos, muares eram os animais originários do outro lado do Atlântico que nesse momento marcavam a sua presença nos territórios da margem leste do Tibagi, nas regiões dos Campos Gerais. Algumas espécies de plantas introduzidas pelas populações adventícias como laranjas, bananas, arroz e feijão apareciam nas fazendas nos Campos de Curitiba e nos Campos Gerais. Boa parte da bacia do rio Tibagi é recoberta pela formação vegetal denominada de Campos Gerais, como pode ser visto na Imagem 1. Em destaque verde, pode ser perceber a presença dos campos no alto da bacia e a leste da mesma. ${ }^{27}$

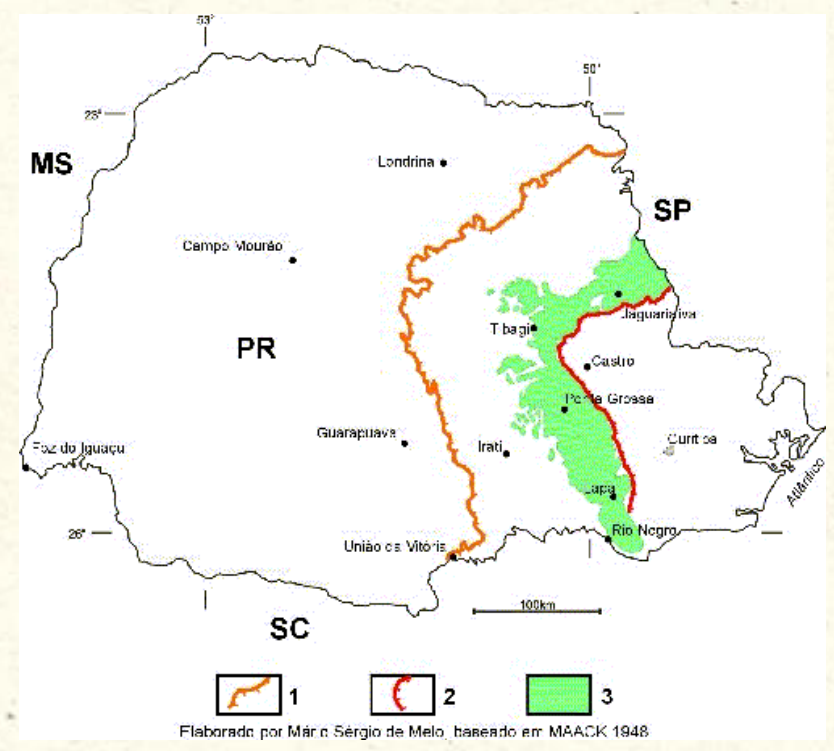

Imagem 1 - Formação dos Campos Gerais. 1: Escarpa da Serra Geral; 2: Escarpa Devoniana; 3: Extensão original dos campos naturais no Segundo Planalto Paranaense. Fonte: «http://www.uepg.br/dicion/campos_gerais.htm». Acesso em: 11 abr. 2011.

A partir da década de 1840 houve várias tentativas de reconhecimento e mapeamento dos cursos dos rios Tibagi, Paranapanema, Ivaí etc. Patrocinadas pelo Barão de Antonina, ficaram conhecidas como 'entradas' e foram comandadas principalmente por Joaquim Francisco Lopes e pelo piloto e cartógrafo inglês John H. Elliot. Menos de uma década após as primeiras 'entradas' que teriam ocorrido em 1845, foi criada a Colônia Militar de Jatay, em 1851. Logo em seguida, em 1855, foi criado o Aldeamento de São Pedro de Alcântara, às margens do rio

27 - Os campos gerais é definição sobre uma determinada região, assim entendida: A expressão "Campos Gerais do Paraná" foi consagrada por MAACK (1948), que a definiu como uma zona fitogeográfica natural, com campos limpos e matas galerias ou capões isolados de floresta ombrófila mista, onde aparece o pinheiro araucária. Nessa definição, a região é ainda limitada à área de ocorrência desta vegetação que a caracteriza situada sobre o Segundo Planalto Paranaense, no reverso da Escarpa Devoniana, a qual o separa do Primeiro Planalto, situado a leste. Ver Imagem 1. Conforme «http://www.uepg.br/dicion/campos_gerais.htm»Acesso em: 11 abr. 2011. 
Tibagi. A colônia e o aldeamento estavam situados a cerca de $60 \mathrm{~km}$ da sua foz no rio Paranapanema. Um pouco mais à montante foi criado, em 1859, 0 aldeamento de São Jerônimo da Serra. A presença das novas formas de apropriação da natureza já havia incorporado, pelo menos simbolicamente, cerca de 500 km do curso total do rio. Em 1860, John Enrique Elliot desenhou uma corografia da estrada que ia da cidade de Castro até a Colônia Militar de Jatay e uma corografia da Província do Paraná. 0 espaço natural aparecia agora incorporado por outras formas simbólicas, características da constituição dos estados-nação. A colônia e 0 aldeamento estão inseridos dentro das estratégias do Governo Imperial de consolidar a presença do estado nos limites fronteiriços com outros países, bem como de efetivar a ocupação dos espaços internos do território nacional. Iniciava-se o tempo da presença e da transformação do baixo Tibagi a partir de produtos e novas técnicas: cana de açúcar, cavalos, bois, porcos, galinhas, feijões, arroz e outros produtos e técnicas como alambique, casas de tijolos cobertas por telha de barro e, finalmente, o mais importante indício da 'transformação da natureza', a introdução da agricultura nos moldes do velho mundo.

Um novo marco significativo da coevolução dos humanos e o mundo natural na bacia do Tibagi, especialmente na sua parte baixa, pode ser apontado na expansão da produção cafeeira. Em meados do século XIX iniciava-se a expansão da cafeicultura no nordeste da Província do Paraná. ${ }^{28}$ Durante quase uma centena de anos, a cafeicultura foi o motor da 'grande transformação' pela qual a parte baixa da bacia passou até os anos de 1960/1970, quando foi substituída, majoritariamente, pelo cultivo de outra espécie exótica: o feijão soja. A introdução da cafeicultura representa a evidência maior de que o processo da 'grande transformação' da natureza na 'mercadoria fictícia terra' estava em marcha para se tornar dominante. Ainda assim, seriam necessários pelo menos mais sete décadas até que a 'marcha', como foi denominada a expansão do cultivo do café, ultrapassasse os espigões do rio Cinza, do Laranjinha e as margens do Tibagi, instalando-se a oeste, na região de sua foz no rio Paranapanema. ${ }^{29}$

Mas, uma vez ultrapassada a margem oeste do rio Tibagi, em fins da década de 1920, a grande transformação não demorou mais do que 30 anos para chegar às barrancas leste do rio Paraná. A grande floresta estacional semidecidual, que cobria o território circunscrito pelos cursos baixo do Tibagi, da margem sul do Paranapanema, pelo rio Piquiri e Ivaí, estava em processo acelerado de desaparecimento. A introdução e expansão, principalmente, da espécie exótica Coffea arabica, o café, juntamente com dezenas de outras espécies vegetais e animais, caracterizaram o processo de coevolução que se tornou hegemônico, de uma parte da espécie humana, os descendentes de europeus e africanos, com a parte baixa da bacia do rio Tibagi, do final do século XIX até a década de 1960. Constituiu-se uma 'segunda natureza', organizada pelos humanos e pelos seus objetos técnicos, como pontes, estradas e ferrovias, máquinas e carros, cercas, açudes, drenagens, sítios, fazendas, casas e cidades.

Após a Segunda Guerra Mundial, com a introdução em larga escala da 'agricultura química", surgem novos componentes técnicos: adubos e agrotóxicos, que causariam grandes impactos socioambientais sobre os moradores humanos e não humanos da zona rural e urbanos, como os da cidade dé Londrina, surgida no início dos anos de 1930. Essa cidade, situada na margem esquerda do baixo Tibagi, é um exemplo claro desta nova forma de ocupação e utilização do espaço desencadeada pela 'grande transformação'. Com oito décadas de existência conta com cerca de 500.000 moradores.

Os processos mencionados podem ser mais bem avaliados considerando o crescimento da presença de humanos na bacia. Vejamos apenas o grande movimento populacional ocorrido após os anos de $1940 .{ }^{30}$ De uma população estadual total estimada em cerca de 380 mil para a década de 1940, ela evolui para cerca de 1.500 .000 no início dos anos de 1990. Ocorreu também uma radical mudança nos locais de moradia dos residentes: em 1940, dos 380 mil, menos de 90 mil moravam na zona urbana. Em 1990, dos 1,5 milhão, a população rural não passava de 330 mil. As cidades e as transformações ocorridas na organização da natureza para fins agrícolas, em especial com o surgimento da 'revolução verde' e, mais recentemente, do complexo do agrobusiness,

\footnotetext{
${ }^{28}$ Em 1854 foi criada a Província do Paraná; até essa data o território que se tornou paranaense era conhecido como a quinta comarca da Província de São Paulo.

${ }^{29}$ Essa 'marcha' não tinha um único sentido e nem se originava de apenas um único pólo irradiador, ou seja, a região do nordeste do Paraná. Outros fluxos vindos do norte, da região de Assis, no Estado de São Paulo, no médio Paranapanema, também faziam parte dessa "marcha". Em 19160 Governo do Estado do Paraná concedeu à empresa Corain e Cia e a Leopoldo Paula Vieira cerca de 50 mil hectares cada um, para 'colonização. A primeira concessão estava situada onde atualmente se localiza 0 município de Primeiro de Maio, na foz do Tibagi no Paranapanema; a segunda onde hoje se encontra o município de Sertanópolis. Em 1925, mais a noroeste do Estado do Paraná, no baixo Paranapanema, estava demarcada uma outra concessão à empresa BRAVIACO, com divisas nos rios Paraná e Ivai. Cf. Nelson Dácio Tomazi. "Norte do Paraná": histórias e fantasmagorias.(Tese de Doutoramento-Universidade Federal do Paraná) 1997, 173; Jayme Antonio Cardoso e Cecilia Maria Westplhalen. Atlas histórico do Paraná. Curitiba: Livraria Editora do Chain, 1986. 62-63.

${ }^{30}$ A população total do estado do Paraná no início do século XX em pouco ultrapassava a casa dos 400 mil habitantes.
} 
representam duas das̀ maiores evidências das mudanças significativas na coevolução recente de determinadas populações humanas com a bacia do rio. 0 surgimento do mundo urbano e as transformações na agricultura estão interconectadas. Em um primeiro momento, as cidades serviram como suporte para as transformações que estavam ocorrendo no mundo natural, embora elas representassem uma mudança radical nas formas de morar $\mathrm{e}$ ocupar o mundo natural. Em um segundo momento, com o crescimento das populações urbanas, a dinâmica dos processos realizados no campo passou a ser determinada pelo mundo urbano, devido às imensas demandas de produtos necessários à sobrevivência dos humanos e para o funcionamento dos objetos técnicos desta forma de morar e viver.

É nesse último período, o do esvaziamento humano do campo e urbanização acelerada, resultado da implementação do complexo do agrobusiness (soja, milho e trigo) de produção em grande escala e em grandes extensões, a partir dos anos de 1970, que um outro movimento começa a ser notado nessas regiões, em particular na cidade de Londrinà-PR. Aí, na região que tinha sido fronteira agrícola até os anos de 1960; porta de entrada do complexo do agrobusiness no final dessa década; evidência da urbanização e do esvaziamento populacional do campo, a 'era da ecologia' dava seus primeiros sinais de aparecimento. Nessa temporalidade, a água e o rio passam a receber novos significados e se tornam alvo de novos conflitos. 0 rio torna-se objeto de atenção porque pode atender à crescente demanda por água potável impulsionada pelo aumento da população urbana mencionada. A urbanização e as transformações no processo produtivo da agricultura, especialmente, 0 incremento de químicos (adubos e venenos) tornaram, ou criaram, a percepção de que suas Águas estavam poluídas. A emergência do rio Tibagi como abastecedor de água potável e a descoberta de sua poluição serão os objetos de análise a seguir.

\section{Os rios, os homens e a historiografia}

No início dos anos de 1970, a crescente demanda por água potável gerada pelo crescimento urbano, e por longos períodos de estiagem na região, levou o governo do município a propor projetos com objetivo de resolver 0 problema do abastecimento de água potável para os habitantes e para 0 setor industrial da cidade.$^{31} 0$ então prefeito de Londrina, Dalton Paranaguá, contratou os serviços de uma empresa de consultoria e saneamento: a Planidro - Enaldo Cravo Peixoto (ECP), para realizar estudos técnicos e econômicos de sistemas individuais e coletivos para 0 abastecimento de Londrina. Esses estudos deram origem a uma proposta que viria ser conhecida, em 1974, como Projeto Tibagi. Esse projeto, elaborado pela ECP, consistia na construção de um sistema integrado de captação das águas do rio Tibagi. ${ }^{32}$

Entretanto, havia outras possibilidades de atender a demanda por água potável para os habitantes de Londrina. Em 1976, ano no qual o Relatório Técnico Preliminar do Projeto Tibagi foí enviado ao Banco Nacional de Habitação (BNH), para análise, em 1976, foram realizados testes para a perfuração de um poço com o objetivo de atingir o Aquífero Guarani, naquela época conhecido como Aquífero Botucatu. ${ }^{33}$ Desta forma, a possibilidade de captação de águas subterrânea tornou-se uma alternativa para 0 abastecimento de água potável. A captação das águas do aquífero já supria várias cidades do estado de São Paulo, como registrou a Folha de Londrina em 1977:

0 poço tubular profundo que a Administração de Recursos Hídricos está perfurando em Londrina para a captação de água subterrânea atingiu esta semana a profundidade de 210 metros. A água será injetada no sistema de

\footnotetext{
${ }^{31}$ Importante lembrar que o regime militar que comandou o Brasil no período de 1964 a 1985 tinha, especialmente como foco o "desenvolvimento econômico a qualquer custo" do país.

${ }^{32}$ Amanthea, Nelson R. De volta para o futuro: O Aquifero Guarani como alternativa viável ao desenvolvimento da região de Londrina. 2004. 287fLS. Dissertação (Mestrado em Administração) - Programa de Pós-Graduação em Administração - Universidade Estadual de Londrina e Universidade Estadual de Maringá. 2004. A ideia era, também, fornecer água potável para várias cidades vizinhas como Cambé, Rolândia, Arapongas, Apucarana, Cambira, Jandaia do Sul e Marialva.

${ }^{33} 0$ Aquífero Guarani é o maior reservatório subterrâneo transfronteiriço de água doce do mundo, situado na porção Centro-Leste do continente sul-americano. Suas águas estendem-se pelo território da Argentina, Brasil, Paraguai e Uruguai. No Brasil o aquífero se estende pelas regiões central e oeste de São Paulo, Triângulo Mineiro, Região sul de Goiás, porção sudeste de Mato Grosso, Mato Grosso do Sul, Santa Catarina, Rio Grande do Sul e Paraná. No Paraná 0 aquífero ocupa 66\% do seu território, principalmente a região norte do Estado. Ver a este respeito: Rocha, G. A. "0 grande manancial do Cone Sul." In Estudos Avançados 11, 30 (1997): 191-212; Gastmans, D, C. H. Kiang. "Avaliação da hidrogeologia e hidroquímica do Sistema Aquífero Guarani (SAG) no estado de Mato Grosso do Sul." In Revista Águas Subterrâneas 19, 1, (2005): 35-48, e Ribeiro, Walter C. "Aquífero Guarani: gestão compartilhada e soberania." In Estudos avançados 22,64 (2008): $227-238$.
} 
abastecimento de Londrina e propiciará a redução dos custos operacionais, já que 0 manancial subterrâneo dispensa tratamento suplementar. Conforme 0 cronograma da Secretária do Interior, a obra deve estar concluída até maio próximo. 0 aquífero Botucatu, que será atingido pela obra, tem suas características bem conhecidas, principalmente no Estado de São Paulo, onde cidades como Ribeirão Preto são inteiramente abastecidas por poços tubulares. ${ }^{34}$

Aparecia, assim, através de matérias jornalísticas uma disputa em torno da forma como os habitantes da cidade de Londrina seriam abastecidos com água potável. Essa disputa se estenderia pela década seguinte, tendo 0 governo do estado optado pela captação das águas do rio Tibagi. Transcorreram quase vinte anos, entre o início dos anos de 1970, quando apareceu primeiramente a ideia da captação, e 1991, quando foi inaugurado o sistema. Os argumentos usados, especialmente pelos contrários a captação das águas do rio Tibagi, revelam, como veremos adiante, uma transição entre a questão econômica e os novos significados para o rio, nos termos da 'era da ecologia: poluição e água pura.

Após as primeiras perfurações não terem sido bem-sucedidas, houve o abandono da ideia por parte do governo do Estado. Então, o diretor da empresa que realizava a perfuração anunciava através da imprensa os possíveis motivos para a decisão dos órgãos governamentais. Em matéria do dia 23 de março de 1978, com título "Por que 0 Governo abandonou a perfuração do poço da ARH?", em destaque, a Folha de Londrina informava que o empresário estava suspeitando que a obra tivesse sido abandonada pelo governo, em virtude de interesses econômicos, já que para o empresário, abastecer a cidade com água do Aquífero Botucatu sairia muito mais barato do que a captação no Rio Tibagi.

A declaração do empresário repercutiu e gerou, inclusive editoriais do principal jornal da cidade, a Folha Londrina. Em editorial de março de 1978 aparecia a cobrança por esclarecimento sobre a paralisação da exploração do aquífero: "A denúncia formulada pelo responsável pela empresa que perfurou o poço da ARH, para a tentativa de captação de água do aquífero Botucatu, deve merecer, rapidamente, uma palavra oficial e esclarecedora da SANEPAR, da Secretária do Interior, ou até do Governo do Estado." 35

$\mathrm{Na}$ continuidade do editorial, o jornal se posiciona pela captação através da exploração do aquífero. Esse posicionamento, abriria espaço, mais tarde, para movimentos sociais da cidade questionarem a decisão pela captação das águas do rio Tibagi.

Como se sabe, visando atingir o importante lençol de água denominada aquífero Botucatu, cujo potencial seria suficiente para resolver os problemas de abastecimento do produto a toda a região. Todavia, de qualquer forma, ainda que seja preciso perfurar mais 5 ou 6 poços, e com o conhecimento adquirido no primeiro, o serviço fica mais fácil e barato, 0 custo seria infinitamente inferior ao do aproveitamento da água do Tibagi, e a solução seria também mais rápida. Ora, então por que parar agora? Haverá razões objetivas ou, de fato terão surgido "interesses ocultos". 36

Nota-se que 0 argumento principal era sobre os custos econômicos. Por parte do governo do Estado, logo após a publicação deste editorial, o Secretário do Interior veio a público explicar o porquê do abandono do poço. Noel Lobo Guimarães explica, "a perfuração foi interrompida por falta de recursos orçamentários" 37 . Entretanto, dois meses após, a perfuração foi retomada, projeto visando à abertura de mais poços para abastecer outras cidades na região38. No anúncio do reinício da prospecção, toma forma a oposição entre as duas opções: 'aquifero versus Tibagi', a polêmica estava publicizada e assumida por parte do governo do Estado. No entanto, após mais alguns insucessos, no início do ano seguinte, o secretário do interior do Estado do Paraná, Renato Antonio Johnson, informou que se as obras de perfuração do Aquífero Botucatu "não dessem certo, Londrina seria abastecida com as águas do Tibagi e, por isso, a SANEPAR continuaria com os estudos do projeto de captação de água do rio Tibagi." ${ }^{39}$ Aparentemente, até esse momento, 0 aquífero seria a alternativa principal para resolver a falta de água em Londrina. Um mês após a declaração de Renato Antonio Johnson, em abril de 1979, a Folha

\footnotetext{
34 "Perfurados 210 metros no poço profundo da ARH". Folha de Londrina, 15 fev. 1977, 3.

35 "A denúncia sobre o poço". Folha de Londrina, 24 mar. 1978, 2.

36 "A denúncia sobre o poço", 2.

37 "Noel Lobo explica abandono do poço: acabou o dinheiro". Folha de Londrina, 14 abr. 1978, 5.

38 "Para breve o reinício do poço tubular". Folha de Londrina, 20 maio 1978, 4.

39 "Secretário do Interior: Tibagi abastecerá Londrina se o Botucatu não der certo". Folha de Londrina, 28 mar. $1979,4$.
} 
de Londrina publicava uma matéria com o seguinte título "Encontrado aquífero Botucatu: água a 840m de profundidade". 0 texto informava, sobretudo, a forma com que a empresa iria proceder para retirar a água do poço, dos estudos que seriam realizados para iniciar o seu aproveitamento e da quantidade de novos poços que precisariam ser perfurados para atender a população até 0 ano $2000 .^{40}$

Porém, o exame da água captada no aquífero revelou uma quantidade flúor acima do aceitável para consumo. Esse fato tornou-se argumento em favor da captação das águas do rio por parte dos dirigentes da Companhia de Saneamento e Águas do estado, a SANEPAR. Apesar do sucesso da perfuração do poço n’2 e com a execução do poço n 3 já iniciada, em setembro de 1979, o governo anunciava que iria investir no Projeto Tibagi caso houvesse a necessidade de aplicar dinheiro no processo de remoção do flúor das águas subterrâneas, uma vez que essa técnica encareceria as obras dos poços. E, por isso, o Sistema Tibagi seria mais viável, como podemos conferir por meio da entrevista do Secretario do Interior concedida a Folha de Londrina: "Caso haja necessidade de instalação de unidade para a remoção do flúor (hipótese do índice permanecer em torno de 10 ppm), este custo seria acrescido de mais $\mathrm{Cr} \$ 8$ milhões. Portanto verifica-se que a solução Tibagi para a mesma vazão de água, será bem mais viável."41

Mesmo depois de encontrada uma solução mais barata para resolver o problema da quantidade de flúor das águas do aquífero, ${ }^{42}$ a SANEPAR em 1981, realizou um estudo comparativo econômico e financeiro para conferir qual das dúas alternativas, Botucatu ou Tibagi, seria mais viável para resolver o problema da falta de água em Londrina e região. Optou-se pelo manancial de superfície, o rio Tibagi, alegando a viabilidade econômica e financeira do projeto. Este documento foi muito utilizado pelo governo nos debates e reuniões para defender a captação das águas do Tibagi, porém foi muito questionado pelos contrários ao Sistema Tibagi. Deste modo, não há dúvidas de que para o governo do Estado, especialmente para empresa SANEPAR, o rio Tibagi sempre foi visto como a melhor solução. 0 principal argumento em favor do Projeto Tibagi utilizado, principalmente pelo prefeito de Londrina, era a certeza da disponibilidade de água em quantidade suficiente para atender Londrina e região, mesmo em época de poucas chuvas.

No início de 1978, não havia nos argumentos contrários a captação das águas do rio referência a qualidade. Os principais argumentos eram os fatores econômicos e o tempo de conclusão da obra, uma vez que a população sofria com o racionamento de água devido aos longos períodos de seca na região. ${ }^{43}$ Porém, já no final desse ano, a qualidade da água do Tibagi passou a chamar atenção. Um dos motivos, teria sido o início de pesquisas sobre a qualidade da água no Estado do Paraná, inclusive a dos rios, por parte da Administração dos Recursos Hídricos - ARH. ${ }^{44}$ Em Londrina a ARH começou a investigar a poluição do rio Tibagi e a do Lago Igapó.

Em 25 de novembro de 1978, a Folha de Londrina publicou uma matéria trazendo as seguintes informações obtidas com a ARH,

0 diretor superintendente da ARH - Administração de Recursos Hídricos, [...] informou que o órgão, a exemplo do que vem fazendo periodicamente, procederá em breve a análise em alguns pontos do rio Tibagi para averiguar 0 índice de poluição ali existente, já que aquele rio recebe quase diariamente diversos produtos químicos altamente tóxicos que são lançados pela Iparse - Indústrias Reunidas Paranaenses, de Jataizinho, além de resíduos do Frigorífico Tibagi e da fábrica de papel Klabin, de Telêmaco Borba. ${ }^{45}$

Desde então, um número maior matérias sobre a poluição dos recursos hídricos de Londrina e região começou a tomar conta das páginas dos jornais. Nessas publicações apareciam informações sobre as prováveis causas da poluição, os resultados das pesquisas desenvolvidas pelos institutos do Estado, a visão dos moradores

\footnotetext{
40 "Encontrado 0 aquífero Botucatu: água a 840 m de profundidade". Folha de Londrina, 20 abr. 1979, 4.

41 "Johsson reafirma: Governo investirá no projeto do rio Tibagi". Folha de Londrina, 27 set. 1979, 5

${ }^{42}$ Segundo Nelson Amanthea os estudos realizados pelas as autoridades na área indicaram que a solução mais adequada para resolver o problema da quantidade de flúor na água era realizar a mistura das águas subterrâneas com águas superficiais. Em 1981 a Sanepar anunciou a interligação do poço n.2 ao Cafezal, no entanto não foi realizado. Amanthea, Nelson. Entrevista concedida a Gilmar Arruda, janeiro de 2009, Londrina.

43 "A denúncia sobre o poço". Folha de Londrina, 24 mar. 1978,

${ }^{44}$ Administração de Recursos Hídricos - ARH com a aprovação do Decreto Estadual no 5956, de 06 de dezembro de 1978, passou a denominar-se SUREHMA Superintendência dos Recursos Hídricos e Meio Ambiente. Em 1992, houve a sua fusão com o Instituto de Terras Cartografia e Florestas - ITCF, dando origem ao atual Instituto Ambiental do Paraná - IAP, hoje vinculado à Secretaria de Estado do Meio Ambiente e dos Recursos Hídricos - SEMA.

45 "ARH procederá análise no rio Tibagi e acha "seríssimo" o problema do Igapó". Folha de Londrina, 25 nov. $1978,5$.
} 
em relação à degradação dos mananciais e, especialmente, as ações da primeira associação ambientalista de Londrina, a Associação Paranaense de Proteção e Melhoria do Meio Ambiente (APPEMMA). ${ }^{46}$

A reportagem seguinte, demonstra 0 interesse desses órgãos e da imprensa sobre as questões ambientais do município, e para os objetivos desse texto, como eram apresentados, especialmente dentro do contexto de expansão do ideário ecologista e a polêmica sobre as opções para o abastecimento de água potável na cidade.

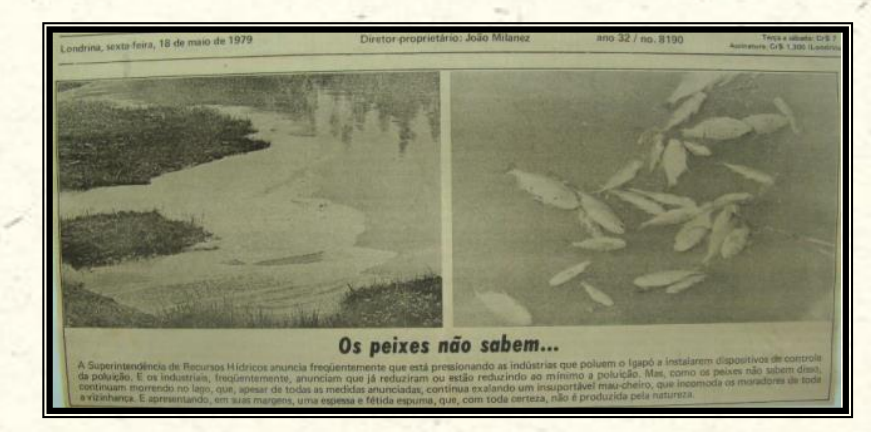

Imagem 2 - "Os peixes não sabem". Folha de Londrina, 18 maio 1979, 1. Acervo: Centro de Documentação e Pesquisa Histórica - CDPH - Departamento de História/Universidade Estadual de Londrina. Foto: Gilmar Arruda.

Nessa imagem, 0 texto acompanha e reforça a mensagem das fotos de peixes mortos boiando, contribuindo para a ampliação da percepção da vulnerabilidade da natureza e da poluição provocada pelos humanos, ou seja, a emergência da era da ecologia em Londrina. ${ }^{47}$ Assim, neste momento da emergência de pesquisas e denúncias a respeito das fontes poluidoras, os órgãos ambientais constataram que os agrotóxicos também eram responsáveis pela poluição dos rios. Deste modo, a Superintendência de Recursos Hídricos e Meio Ambiente do Paraná SUREHMA começou a investigar também as consequências dos efeitos dos agrotóxicos para o meio ambiente e para a população. Aparece aqui uma estreita relação entre matérias da imprensa e as ações decorrentes da APPEMMA, em especial as declarações do engenheiro agrônomo Marco Antonio Castanheira. ${ }^{48}$

Nas atividades da APPEMMA, percebidas através de Marco Antonio Castanheira, e nos movimentos de oposição a captação das águas do rio Tibagi, lideradas principalmente pelo engenheiro civil Nelson Amanthea, junto com o Sindicato dos Engenheiros de Londrina, encontramos as evidências da emergência das novas percepções sobre o rio e, também, da 'era da ecologia' na cidade de Londrina. Por isso, faz-se necessário a análise mais detalhada das suas trajetórias, declarações e posicionamentos. Os dois são personagens centrais na questão ambiental de Londrina nos anos 1970 e 1980, o que é fundamental para entender melhor as discussões sobre 0 abastecimento de água em Londrina e assim, identificar as percepções construídas pela a população, ambientalistas e as autoridades públicas sobre o rio Tibagi.

Nascido na cidade de Paulo de Farias, norte do Estado de São Paulo, Marco Antonio Castanheira formouse em Agronomia na Escola Superior de Agricultura Luiz de Queiroz (Esalq/USP), em Piracicaba, em 1972, onde iniciou a sua aproximação com o ambientalismo. Depois de formado, mudou-se para o Paraná, tendo trabalhado inicialmente no Banco do Brasil, como avaliador de plantações. Nesse período, viajava pelos municípios próximos de Londrina, o que teria despertado e aguçado sua percepção do problema da erosão e das consequências do uso dos agrotóxicos na Bacia do Rio Tibagi. ${ }^{49} \mathrm{Em} 1975$, ingressou no Instituto Agronômico do Paraná (IAPAR), saindo no início da década de 1980, para fundar a Cooperativa do Vale do Tibagi (VALCO0P), atividade na qual veio a conhecer mais profundamente os problemas ambientais do rio Tibagi, principalmente a poluição do rio por agrotóxicos e por produtos químicos lançados pelas as empresas.

\footnotetext{
${ }^{46}$ A APPEMMA, criada em 1978, na cidade de Londrina, foi coordenada, desde o início, pelo engenheiro agrônomo Marcos Antonio Silveira Castanheira. A ação dessa associação havia iniciado com denúncias e protestos sobre a poluição de um lago artificial da cidade, constituído nos anos de 1950, que havia se tornado cartão-postal da cidade: 0 Lago Igapó. Envolveu-se também nas discussões sobre o Projeto Tibagi, especialmente denunciando a poluição das águas do rio Tibagi, contaminada, segundo Marco Castanheira, por organoclorados oriundos da lavoura altamente tecnificada que estava se expandindo na bacia desde 0 início dos anos de 1970.

${ }^{47}$ A "era da ecologia" é um termo criado pela mídia americana nos anos de 1970 para descrever a grande comoção ecológica que tomava conta do país naquele período.

48 "Surehma pesquisa ações dos pesticidas no meio ambiente". Folha de Londrina, 24 fev. 1979, 5; "Castanheira: Sou contra o Projeto Tibagi". Folha de Londrina, 19 maio 1983, 5.

${ }^{49}$ Como já mencionado, após a década de 1960 a cidade de Londrina sofreu transformações no seu setor agropecuário, em virtude da política de racionalização da cafeicultura no país, com isso um novo padrão de agricultura tecnificada foi implantado, gerando maior degradação ambiental com o uso intenso de agrotóxicos e a erosão do solo com um número maior de áreas desmatadas.
} 
Conhecia o rio Tibagi, conhecia pela minha própria atividade profissional. A cooperativa (VALCOOP) abrangia 09 municípios, todos lindeiros ao rio. Então a questão do Tibagi, a gente começou a levantar muito antes da questão da água para Londrina, com o problema da Klabin. 0 primeiro problema do rio Tibagi, antes da questão da água, já conhecido e denunciado era o problema da Fábrica de Papel e Celulose Klabin, 0 da lixívia negra. ${ }^{50}$

0 depoimento indica que a percepção de que havia poluição no rio Tibagi já circulava antes do surgimento da polêmica 'aquifero versus Tibagi' na cidade de Londrina. Porém, até o final dos de 1970, as denúncias, ou constatação da poluição provocada pela empresa Klabin, não afetava diretamente os habitantes da cidade de Londrina. ${ }^{51} 0$ rio Tibagi, apesar de estar a cerca de 20 quilômetros do centro urbano de Londrina, aparentemente, não fazia parte do cotidiano da maioria de seus moradores, a não ser em atividades esporádicas de lazer, como pescaria. 0 que se percebe, do depoimento de Marco Antonio Castanheira, é que já existiam denúncias sobre a poluição do rio, anteriores a 'questão da água', mas teria sido somente com o projeto de captação das suas águas para 0 abastecimento da cidade que trouxe para o cotidiano dos habitantes a existência do rio e de seus problemas, isto é, o da poluição.

Castanheira, atuou na Associação dos Engenheiros Agrônomos de Londrina, entre 1975 e 1979, na qual envolveu-se com aś discussões sobre a degradação do solo e da contaminação do rio Tibagi pelos agrotóxicos.

A Associação começou a mostrar isto para a população, a questão dos venenos agrícolas, da erosão e de muitas outras coisas desta natureza. As outras entidades da comunidade começaram a se sensibilizar. A Sociedade Rural, que é uma sociedade, vamos dizer assim, vestuta, tradicional, também se sensibilizou. Na época o seu presidente era 0 Antonio Fernandes Sobrinho, que tinha uma mente aberta, um cidadão avançado. A Sociedade Rural se sensibilizou. 0 Rotary Club, a Associação Comercial também começou a me ouvir, a me dar espaço. ${ }^{52}$

A menção a participação da Sociedade Rural e da Associação Comercial de Londrina, como participando das discussões sobre a poluição e degradação parece estranha, pois são associações que representam os setores sociais diretamente responsáveis pela degradação e poluição, como os agricultores e comerciantes de agrotóxicos. Mas, por outro lado, pode se argumentar que a 'questão ambiental', 'defesa da natureza', aparecia naquele momento como uma causa sem opositores. De qualquer forma, ganhando espaço para discutir o processo de degradação ambiental decorrente do uso de agrotóxico, Castanheira conseguiu junto com membros de outras entidades, fundar uma associação com 0 objetivo de mobilizar não só setores diretamente envolvidos com a questão dos agrotóxicos, mas toda a população de Londrina. Assim, em 1978, a APPEMMA, a primeira associação ambientalista de Londrina, sendo Marco Antonio Castanheira, o seu primeiro presidente. Essa associação participaria dos principais embates em torno da 'questão ambiental', entre eles a polêmica 'aquífero x Tibagi' e a criação do Parque Estadual Mata dos Godoy.

Nelson Amanthea, nasceu na cidade de Taquari, Estado de São Paulo, formou-se em Engenharia Civil na Universidade Estadual de São Paulo -USP. Depois de formado, mudou-se para Londrina, em 1978, onde começou a trabalhar na Universidade Estadual de Londrina. Segundo Nelson Amanthea seu interesse pelas águas subterrâneas iniciou quando ainda era criança ao testemunhar a perfuração de um poço artesiano perto de sua casa: "Aquilo foi importante para mim, chegou a ser publicado no jornal de Catanduva, aquela água que veio lá das profundezas e tal. Talvez isso tenha despertado em mim um maior interesse e quando eu estava estudando Engenharia, fiz um projeto de abastecimento de uma cidade através de água subterrânea." 53

Ao chegar a Londrina, tomou conhecimento da perfuração do poço na região para a captação das águas do Aquífero Guarani, deste modo, procurou saber mais sobre o assunto conhecendo então Marco A. Castanheira:

Foi aí então que eu conheci o Marco Antonio Castanheira, passei também a acompanhar o trabalho dele que estava caminhando neste sentido. Só que o Marco Castanheira, ele tinha um conhecimento muito grande do rio Tibagi,

\footnotetext{
${ }^{50}$ Castanheira, Antonio. Entrevista concedida a Gilmar Arruda, fevereiro 2011, Londrina.

51 - A empresa Klabin Celulose está localizada no município de Telêmaco Borba-PR, no médio Tibagi. A distância entre Londrina e Telêmaco Borba, através do curso do rio, ultrapassa $200 \mathrm{~km}$.

52 Idem.

${ }^{53}$ AMANTHEA, Nelson. Entrevista concedida a Gilmar Arruda, janeiro de 2009, Londrina.
} 
da poluição como um todo. E ele falava do Aquífero Botucatu, mas ele não tinha muito conhecimento sobre isso. Então em paralelo eu fui fazendo pesquisa, cheguei até o geólogo responsável pela a perfuração do primeiro poço, que havia sido abandonado, tive acesso ao relatório técnico do Banco Nacional de Habitação que financiou aquele poço, que mostrava a viabilidade de aproveitamento do aquífero abastecimento apesar do elevado teor de flúor. ${ }^{54}$

A relação estabelecida entre os conhecimentos de Marco A. Castanheira quanto à poluição do rio Tibagi e a de Nelson Amanthea, sobre a viabilidade da utilização das águas subterrâneas do Aquífero Guarani, ao serem constantemente divulgadas pela a imprensa local, contribuíram com a formação, ou divulgação, da ideia do rio poluído, e com o surgimento de várias manifestações em oposição ao Projeto Tibagi, como veremos a seguir.

A Folha de Londrina vinha desde 0 final da década de 1970 registrando especialmente as opiniões Marco A. Castanheira, o presidente da APPEMMA, a respeito da qualidade da água do rio Tibagi e suas consequências para consumo humanò. Foram várias, entrevistas, declarações e cartas do ambientalista publicadas pelo jornal.55

Em uma, do mês de agosto de 1982, ocupando a página inteira do jornal, a Folha de Londrina divulgou uma entrevista com Marco A. Castanheira. Nessa entrevista, Castanheira debateu argumentos do diretor-técnico da SANEPAR, Carlos Afonso Teixeira, apontou os índices toleráveis de contaminação por pesticidas segundo a Organização Mundial de Saúde e as consequências do uso de agrotóxicos para a saúde humana:

Castanheira rebateu também o argumento de Teixeira de que técnicos do BNH e da Organização Mundial de Saúde já deram pareceres favoráveis à utilização dessa água. "Mesmo que tenha feito, isto não legitima a atitude." No Paraná, esses venenos estão nas águas tratadas da Sanepar, dentro dos parâmetros da OMS, mas em nível de alerta. E com uma deficiência. No caso dos organismos humanos, esses venenos passam pelo fígado, acumulamse nas gorduras e alteram as resistências naturais do organismo. Mas causam problemas muito maiores, como os graves problemas hepáticos e vários tipos de câncer. ${ }^{56}$

Segundo a matéria, Castanheira, com um mapa em mãos, apontava as fontes de poluição do rio Tibagi com base em seus conhecimentos adquiridos ao longo da carreira profissional, razão pela qual insistia em denunciar a qualidade das águas do Tibagi.

Segundo ele, o único modo de aproveitar corretamente um manancial de superfície, hoje em dia, é o de despoluíIo. E isto implica, conforme explicou, em realizar o tratamento dos esgotos, dos afluentes industriais; de que exista uma agricultura racional, sem veneno, matas ciliares e solo conservado. "0 que demandaria mais de 10 anos, sendo bastante razoável." ${ }^{57}$

Em todo o texto, o jornalista sempre se refere a Marco A. Castanheira como agrônomo ou técnico, com a clara intenção de dar credibilidade às informações. Além de apontar o rio como poluído, bem como as fontes da poluição, aparece na entrevista um novo tema ligado à era da ecologia, o da 'despoluição'. Já não se tratava mais de denunciar, mas sim de tomar atitudes para, num primeiro momento, parar de poluir e, depois, recuperar o que já sido degradado. No caso da região de Londrina, as formas de agricultura praticadas no momento inicial da grande transformação, a cafeicultura e agricultura familiar, foram rapidamente substituídas pelo sistema do agrobussiness, nos anos de 1970. A erosão dos solos, já existente, intensificou-se e apareceu a contaminação por uso excessivo de agrotóxicos. Uma ameaça não visível, nem perceptível no cotidiano. Foi essa ameaça, presente no consumo cotidiano da água do rio que desencadeou e organizou os movimentos de resistência ao 'Projeto Tibagi'.

A necessidade de despoluição do rio Tibagi começou a ser mencionada em vários momentos, especialmente nas discussões sobre 0 abastecimento de água na cidade. Os prognósticos sobre a recuperação do rio, devido à sua longa extensão e as várias formas de poluição, estimavam que a recuperação do manancial

\footnotetext{
54 Idem.

${ }^{55}$ Essas são algumas das reportagens que trazem as opiniões de Castanheira: "APPEMMA questiona a Sanepar sobre 0 aquífero". Folha de Londrina, 3 ago. 1982, 5; "Castanheira insiste na suspensão da licitação". Folha de Londrina, 30 nov. 1982, 5; "Carta: Aquífero e o Tibagi". Folha de Londrina, 23 dez. 1982,2 ; "Projeto Tibagi: Castanheira contesta posição do prefeito". Folha de Londrina, 15 maio 1983, 6; "Castanheira: Sou contra o Projeto Tibagi". Folha de Londrina, 19 maio 1983, 5; "Carta: E a água?". "Castanheira: Sou contra o Projeto Tibagi". Folha de Londrina, 25 maio 1983, 5.

56 "APPEMMA questiona a Sanepar sobre 0 aquífero". Folha de Londrina, 3 ago. 1982, 5.

57 "APPEMMA questiona a Sanepar sopre 0 aquífero", 5.
} 
levaria anos, tornado inviável a utilização do Tibagi para fornecimento de água potável. A utilização do jornal do ponto de vista do presidente da APPEMMA pode ser observada também com o fragmento do editorial do jornal de 1 de dezembro de 1982, já mencionado anteriormente:

No momento em que se discute a suspensão da concorrência para o Projeto Tibagi, principalmente face às queixas de empresas locais de que não podem participar da obra nos termos que foi proposto, o agrônomo, Marco Antonio Castanheira, em carta-aberta, apresenta interessantes e ponderáveis colocações voltando a questionar sobre 0 aproveitamento das águas do aquífero Botucatu. É muito oportuna a colocação daquele técnico, que traz de volta um tema até agora não suficientemente esclarecido, qual seja, o dos motivos que levaram aparentemente abandono do projeto "Botucatu" para dar lugar ao "Tibagi". Há muitas outras ponderações importantes na referida carta aberta. Cita-se ali que a água disponível no aquífero pode abastecer durante um ano 270 bilhões de pessoas, isto é 70 vezes a populàção atual da terra. E há um detalhe há constante renovação no aquífero, o que lhe dá condições quase de um reservatório inesgotável. Um reservatório que pode ter água com excesso de flúor, mas que não tem toda a contaminação das águas dos rios que existem hoje, em toda parte. ${ }^{58}$

A presença constante de Castanheira nas páginas do jornal Folha de Londrina, nos indica que havia uma certa concordância do jornal em relação às opiniões e posições do agrônomo. Senão entre os diretores, pelo menos entre os editores e jornalistas. Um outro aspecto ilustra a facilidade de acesso que Castanheira tinha ao jornal. No final de dezembro, no dia 22, o jornal publicou uma carta do leitor Antonio Tunnoti, da cidade de Londrina. Na carta intitulada 'Aquifero e Tibagi', o missivista destaca que o projeto de 'ampliação e melhoria do abastecimento de água na cidade' havia desencadeado uma 'onda de manifestações contrárias a captação do Tibagi e a favor do Aquifero Botucatu.'59 0 leitor desqualifica os que se posicionam a favor do aquífero afirmando que eles não seguiam o 'princípio da globalidade inerente a essa tão nobre ciência que é a Ecologia', e que também não se entendia o 'estado de silêncio que se encontrava os raivosos manifestantes, não se levantando essa importante questão do envenenamento bem antes' e, continua, que as simpatias pelo aquífero parecem ser impulsionadas por um 'forte emoção de experimentar aquela água proveniente de um gigantesco e misteriosos reservatório subterrâneo. '60 0 franqueamento do jornal a Marco Castanheira se comprova, pois já no dia seguinte é publicada uma carta resposta de sua autoria, na qual responde aos questionamentos de Antonio Tonoutti. Nela, ironizando o fato do desconhecimento da ação em defesa do Lago Igapó; na luta por rede de esgotos, etc, dizia que o missivista só poderia ser de outra cidade. Procurando demonstrar que não existiria subjetividade e nem precipitação, nem mesmo seria um 'reservatório misterioso', pois existiam várias cidades que o utilizavam; que as águas subterrâneas correspondiam à maior parte da água doce disponível no planeta. Procurava, nessa carta, colocar sua resposta baseada em termos técnicos, apesar das ironias. ${ }^{61}$

Em uma outra matéria, no ano seguinte, no dia 15 maio de 1983, novamente as opiniões do presidente da APPEMMA aparecem na imprensa. Nesta matéria 0 ambientalista questionava 0 prefeito de Londrina, Wilson Moreira, por ter apoiado a captação das águas do rio Tibagi:

É temerário defender a implantação de um projeto que envolve o custo extraordinário, calcado em cima de hipóteses e incertezas, e com isso colocar em jogo a saúde da população. A afirmação é do agrônomo Marco Antônio Castanheira, feito ontem em tom de contestação as colocações do prefeito Wilson Moreira, que sexta-feira, contrariando toda a expectativa da comunidade e inclusive seu próprio posicionamento anterior, defendeu o início imediato de execução da primeira etapa do Projeto Tibagi. Castanheira tem uma certeza: "A qualidade da água do Tibagi é muito mais incerta do que a do Botucatu". Mesmo por que - assegurou - as águas subterrâneas oferecem maior segurança que os mananciais de superfície, sempre sujeitos a desastres ecológicos [... ${ }^{62}$

\footnotetext{
58 "A água em debate". Folha de Londrina, 1 dez. 1982, 2.

${ }^{59}$ Folha de Londrina, 22 dez. 1982, 2.

${ }^{60}$ Folha de Londrina, 22 dez. 1982, 2.

61 "Aquifero Botucatu", Seção Carta dos Leitores, Folha de Londrina, 23 dez. 1982, 2.

62 "Castanheira questiona posição do prefeito". Folha de Londrina, 15 maio 1983, 6.
} 
Apare, agora, còm essa entrevista, um deslocamento muito mais claro dos argumentos usados na discussão sobre 0 abastecimento da cidade. Da questão econômica, que estava presente nos primeiros debates sobre a prospecção do aquífero, ainda em 1977, volta-se agora para o motivo da qualidade da água. Além disso, a contraposição aguas superficiais versus águas subterrâneas é o centro do embate baseado no maior ou menor risco, concretos ou não, de 'desastres ecológicos', que poderia afetar uma ou outra.

Nota-se claramente com este texto qual foi a posição do jornal, em relação à polêmica do abastecimento de água na cidade e a concordância de opiniões entre os editores e o ambientalista. Os articulistas do editorial, para mostrar a inviabilidade da captação das águas do rio Tibagi, trazem informações de toda a trajetória do aproveitamento das águas do Aquífero Botucatu, enaltecendo o baixo custo econômico do projeto Botucatu comparado ao projeto Tibagi. Porém, o principal argumento dos editores a respeito da qualidade das águas do aquífero era uma afirmação feita por Castanheira sobre a poluição do rio Tibagi. Deste modo, os conhecimentos de Marcos Antonio Càstanheira fundador da APPEMA, tinham se tornado referência para a exposição da opinião do jornal. Assim, na medida em que os rios estavam poluídos, sobretudo o rio Tibagi, por agrotóxicos e por outros produtos químicos altamente tóxicos lançados por empresas, essa não era a melhor opção para resolver 0 problema da falta de água na cidade, mas sim, as águas "puras" do aquífero.

Deste modo, a concordância e divulgação pela imprensa das opiniões, em especial, do presidente da APPEMMA sobre o rio Tibagi contribuiu para que a população construísse uma imagem do rio. Percepção essa que pode ser verificada por meio das cartas de leitores publicadas pela imprensa. Em 18 de dezembro de 1982 , a Folha de Londrina publicou uma carta produzida por alguns leitores do jornal que se declaravam como mães de família, médicos, advogados, estudantes, vereadores e etc. A carta era dirigida ao governador do Estado, José Hosken de Novaes: 0 texto expõe claramente a preocupação da comunidade com a falta de água, principalmente com a solução que o governo poderia optar. Os leitores deixavam claro que eles conheciam por meio do noticiário regional que existiam duas opções para abastecer a cidade, uma "captar água do rio Tibagi, um dos rios mais poluídos do Paraná", e a outra opção "que vigorosamente vinha sendo defendida por especialistas, é a exploração do aquífero Botucatu, manancial incontaminável, que poderá nos fornecer água por centenas de anos." 63 Em outra parte do texto falam sobre as opiniões de associações, políticos, agrônomos e ecologistas acerca do projeto de captação das águas do Tibagi, bem como, do valor exorbitante para o desenvolvimento do projeto:

\section{Sr. Governador: \\ Dirigimo-nos respeitosamente a v. exa. através da FOLHA DE LONDRINA, no sentido de expor graves preocupações da comunidade, diante de uma de suas necessidades essenciais: a água. 0 Projeto Tibagi, com todos os inconvenientes apontados, além de mais caro, forneceria uma água de qualidade duvidosa, tratado a custos dispendiosos; é um projeto já contestado por dezenas de associações de utilidade pública, políticos, agrônomos e ecologistas. [...]. Exmo Sr. Governador: diante do exposto, apelamos para sua consciência, certos de que sua decisão será tomada de acordo com as reais e vitais necessidades da população, com cautela, discernimento e grandeza, com que tem caracterizado o período de seu governo. Muito Obrigado. ${ }^{64}$}

Observe que os argumentos utilizados pelos leitores são os mesmos publicados em outras matérias do jornal, defendidas principalmente pelo Marco A. Castanheira. Ao fim da carta, com tom de apelo, pedem que 0 governador decida com cautela, discernimento e grandeza, o futuro do abastecimento de água na região. Essa carta é uma evidência do quanto a população de Londrina estava preocupada em consumir as águas do rio Tibagi.

No mesmo ano outra carta em defesa do aquífero, novamente a poluição do Tibagi é o principal argumento. Nesta carta 0 autor critica o prefeito de Londrina por ter apoiado o Projeto Tibagi alegando a possibilidade de despoluição de toda a bacia.

Ora, o Sr Prefeito sugere controlar a poluição em toda a bacia do Tibagi. Pensem em quanto tempo Londrina levou para despoluir (parcialmente o Lago Igapó); porque cidades como Apucarana, Rolândia e outras não conseguem despoluir os rios que as abastece. Esses exemplos são de pequenos mananciais, poucas fábricas estão envolvidas.

\footnotetext{
63 "Água: Tibagi e Botucatu". Folha de Londrina, 18 dez. 1982, 2.

${ }^{64}$ Água: Tibagi e Botucatu", 2.
} 
Agora, o que dizer da bacia do Tibagi, que agrega milhões de pessoas, que cruza áreas de agricultura intensa, que envolve inúmeras cidades? ${ }^{65}$

Em outra carta do mês de junho de 1983, em defesa das águas do aquífero, uma moradora de Londrina descreve 0 seu apoio à luta do agrônomo Marco A. Castanheira. Para a autora, 0 agrônomo representa a maioria dos londrinenses por defender água pura para a população e não as águas contaminadas do rio. 66

Essas fontes nos indicam que a imagem de um rio poluído e venenoso já estava difundida entre a população no início da década de 1980, contribuindo mais tarde com a formação de movimentos contra o Projeto Tibagi, bem como a favor da preservação e recuperação do rio. Em outras palavras, termos como ecologia, poluição, recuperação ambiental, organoclorados, pesticidas, etc, inerentes aos debates sobre a questão ambiental, ou da 'era da ecologia', circulavam entre a população da cidade, constituindo-se em um discurso organizado e coerente em favor de determinada opção e contrária a outra. 0 rio estava poluído e 0 aquífero era puro.

Importante lembrar que as manifestações contra o Projeto Tibagi não ficaram restritas ao município de Londrina, uma vez que o projeto visava atender também várias outras cidades próximas. Em dezembro de 1982 os habitantes de Cambé, cidade vizinha a Londrina, também se manifestaram contra a captação das águas do Tibagi. A matéria ocupou a página inteira do jornal com um título de letras grandes "Cambé não quer água do Tibagi", os habitantes do município deixaram bem claro sua posição em relação à captação das águas do rio Tibagi.

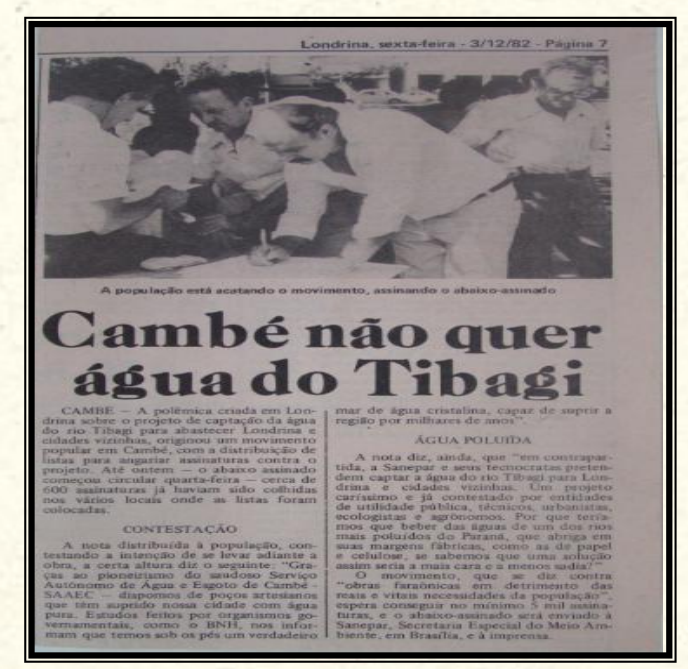

Imagem 3 - "Cambé não quer água do Tibagi". Folha de Londrina, 3 dez. 1982, 7. Acervo: Centro de Dócumentação e Pesquisa Histórica - CDPH - Departámento de História/Universidade Estadual de Londrina. Foto: Gilmar Arruda.

Durante a manifestação foram recolhidas assinaturas dos moradores contra o Projeto Tibagi. Segundo a imprensa, em três dias, cerca de 600 assinaturas já haviam sido colhidas. A reportagem também informava que estudos realizados por especialistas garantiam que os habitantes tinham "sob os pés um verdadeiro mar de água cristalina, capaz de suprir a região por milhares de anos" não sendo necessário, então, consumir as águas poluídas do Tibagi.

No ano de 1982, a polêmica do abastecimento de água em Londrina tornou-se ainda maior, pois segundo Marco A. Castanheira, os empreiteiros locais foram impossibilitados de participar do processo de licitação em virtude das restrições técnicas presentes no edital. Com isso, o movimento dos empreiteiros juntou-se a APPEMMA, ao Sindicato dos Engenheiros de Londrina (SENGE-LD) e a outras entidades com o objetivo de interromper o processo licitatório. As entidades protestavam principalmente, em relação à qualidade da água do rio Tibagi e aos aspectos técnicos e econômicos que levaram a escolha do Projeto Tibagi. A pressão da população,

65 "Aquífero". Folha de Londrina, 20 maio 1983, 2.

66 "Água pura". Folha de Londrina, 9 ago. 1983, 2. 
junto ao interesse de empresários e ambientalistas fez com que o governo interrompesse o processo de licitação.67 Importante lembrar, que neste período o país estava em processo de redemocratização com a volta da eleição para os governos estaduais. É neste contexto, que a sociedade organizada de Londrina e Cambé criou a Comissão Comunitária68 com intuito de discutir e definir junto ao governo do Estado o melhor sistema de abastecimento de água para a região. A Comissão era composta por sindicalistas, empreiteiros, ambientalistas, vereadores e outros, tendo o engenheiro civil Nelson Amanthea como coordenador Técnico. Porém, como todo 0 processo da comissão foi conduzido pelo novo prefeito eleito, em 1982, Wilson Rodrigues Moreira, a Comissão Comunitária, segundo Nelson Amanthea, tornou-se uma fachada para desviar a atenção da população e assim, iniciar novamente o processo licitatório para a construção do Sistema Tibagi ${ }^{69} \mathrm{~A}$ matéria do dia 14 de maio de 1983 confirma a opinião do engenheiro, 0 jornal informava que o prefeito de Londrina decidia defender de vez 0 início imediato das obras do Tibagi, decisão que gerou polêmica em meio à população, uma vez que o prefeito, dias antes, em uma reunião tinha apoiado o trabalho da "Comissão Comunitária" em estudar a melhor alternativa para 0 abastecimento de água de Londrina para que só depois, então, fosse definida a melhor alternativa:

0 prefeito Wilson Moreira defendeu ontem, o início imediato da execução da primeira etapa do Projeto Tibagi, assumindo, desta forma, posição que se choca frontalmente com aquilo que ficou definido no último sábado, durante a reunião entre os membros da Comissão Comunitária encarregada de estudar a melhor alternativa para 0 abastecimento de água de Londrina [...]. Ele sintetizou suas opiniões sobre a poluição do rio Tibagi, comentando que o problema da poluição do rio será solucionado com a redução do emprego de defensivos agrícolas [...], entre outros altamente prejudiciais à saúde. Até que o Projeto Tibagi seja concluído, dentro de dois anos e meio, mais ou menos, o problema do emprego excessivo e indiscriminado de defensivos agrícolas poderá estar solucionado acredita. Assim - segundo disse "é preciso que se comece a lutar por isso a partir de hoje". ${ }^{70}$

Essa matéria deixa claro que, independente dos estudos realizados pela Comissão Comunitária, o Projeto Tibagi seria escolhido pelo poder público como a alternativa mais viável. Nota-se que a imagem do rio Tibagi poluído era encontrada mesmo entre os que defendiam a utilização de suas águas, como é o caso do prefeito. Porém, para Wilson Moreira, a poluição do rio não era considerada grave, uma vez que esse problema poderia ser resolvido com o processo de despoluição do rio durante a realização das obras de captação das águas do Tibagi, ou seja, em três anos. Esse argumento do prefeito foi muito criticado, principalmente, pelos membros da APPEMMA que, com base em suas pesquisas, argumentavam que a despoluição do rio era um processo complexo, podendo levar mais de dez anos para alcançar resultados significativos.

Doze dias após Wilson Moreira divulgar a sua decisão pelo Projeto Tibagi, o jornal Folha de Londrina publicava uma matéria de página inteira com 0 título "Vem aí o Pró - Tibagi: mobilização pelo 0 rio" ${ }^{71} 0$ movimento articulado, pelo prefeito e pelo vice-prefeito, pretendia desencadear ações para a recuperação do rio. 0 texto jornalístico informava, especialmente, acerca das primeiras reuniões de estruturação do movimento assinada por diversos vereadores, prefeitos e empresários, bem como apresentava o ponto de vista das autoridades do movimento. Para eles, a degradação ambiental era atribuída à falta de uma política ambiental firme que contribuísse com a preservação ambiental, por isso, o movimento buscava a participação das prefeituras, lideranças comunitárias e associações de defesa ambiental. No entanto, para Nelson Amanthea, o movimento seria mais uma estratégia do governo para mudar a percepção da população em relação ao rio:

Outra estratégia articulada por Wilson Moreira foi criar uma expectativa, que estavam sendo feitas ações, ou que seria despoluído o rio Tibagi, porque falar que não estava poluído, ninguém açreditava mais. Aí criaram o PróTibagi. Estrategicamente, ele objetivava criar no imaginário popular, uma legitimação da confiabilidade e da qualidade da água e na sequência poderia ser feito sem problema o Projeto Tibagi, a captação de suas águas para abastecer Londrina. ${ }^{72}$

\footnotetext{
67 "Venceu o bom senso". Jornal do Comércio, 16 fev. 1983, 6.

${ }^{68}$ Também denominada de "Comissão Comunitária de Estudos e Análise dos Sistemas de Abastecimento de Água de Londrina e Cambé". Amanthea, Nelson R. De volta para o futuro, 2004.

${ }^{69}$ Amanthea, Entrevista concedida a Gilmar Arruda, janeiro de 2009, Londrina.

70 "Moreira defende execução da $1^{\circ}$ etapa do Projeto Tibagi". Folha de Londrina, 14 maio 1985, 4.

71 "Vem ai o Pró-Tibagi". Folha de Londrina, 15 jun.1983, 5.

${ }^{72}$ Amanthea, Entrevista...
} 
Nas primeiras reuniões do movimento foi estabelecido um grupo de trabalho para afirmar as diretrizes do Pró-Tibagi, bem como a sua comissão coordenadora, entre os seus integrantes estava Marco A. Castanheira. Além disso, em meio às reuniões ficou evidente que a despoluição do rio levaria bem mais que os três anos como afirmava o prefeito de Londrina. Para um dos participantes, o chefe regional do Instituto de Terras e Cartografia (ITC), Hélio Dutra, "o cronograma deve prever um período de pelo menos vinte anos." ${ }^{3}$

Como já mencionado anteriormente, no mesmo período da elaboração do Pró-Tibagi, funcionava a Comissão Comunitária, coordenada por Nelson Amanthea. Dentre alguns trabalhos realizados por essa comissão foi elaborado o Programa Integrado de Saneamento Básico da Grande Londrina, também conhecido como Prosan83. Segundo Nelson Amanthea o Programa "era um compromisso formal do Estado do Paraná para com a sociedade organizada"74 e suas principais recomendações foram: não utilizar a captação do Rio Tibagi antes de ser recuperado, a interlligação imediata do poço existente com o sistema de abastecimento de água já utilizado e a perfuração de mais poços com intuito de resolver em curto prazo o déficit atual do sistema. Porém, no mesmo ano, em 1983, a Comissão foi encerrada e os compromissos assumidos pelo governo para serem iniciados ainda naquele ano não foram cumpridos.

Nos anos seguintes, a Superintendência de Recursos Hídricos e Meio Ambiente do Paraná (SUREHMA) realizou diversas pesquisas no rio Tibagi com intuito de verificar, sobretudo, 0 índice de poluição por agrotóxicos. Acompanhados pela imprensa, os resultados das pesquisas sobre o rio foram divulgados ampliando e materializando a ideia de um rio poluído. Em meados da década de 1980, membros do Sindicato dos Engenheiros de Londrina, entre eles Nelson Amanthea, preocupados com os resultados dos estudos realizados pela SUREHMA, e com a falta de compromisso do Governo do Estado, encaminharam uma carta ao governador José Richa, reivindicando que ele realizasse os compromissos assumidos em 1983, presentes no Programa Integrado de Saneamento Básico da Grande Londrina. Esta carta foi 0 estopim para a articulação de 40 entidades de Londrina ${ }^{75}$ em um movimento popular que passou a ser chamado de Pró-Água, cujo objetivo principal era "[...] de garantir a execução do programa de governo cujas ações haviam sido compromissadas com a sociedade em dezembro de 1983."76

Em dezembro de 1985, o jornal do Sindicato dos Engenheiros de Londrina publicou uma matéria sobre 0 Pró-Água que ocupou a toda a capa do periódico:

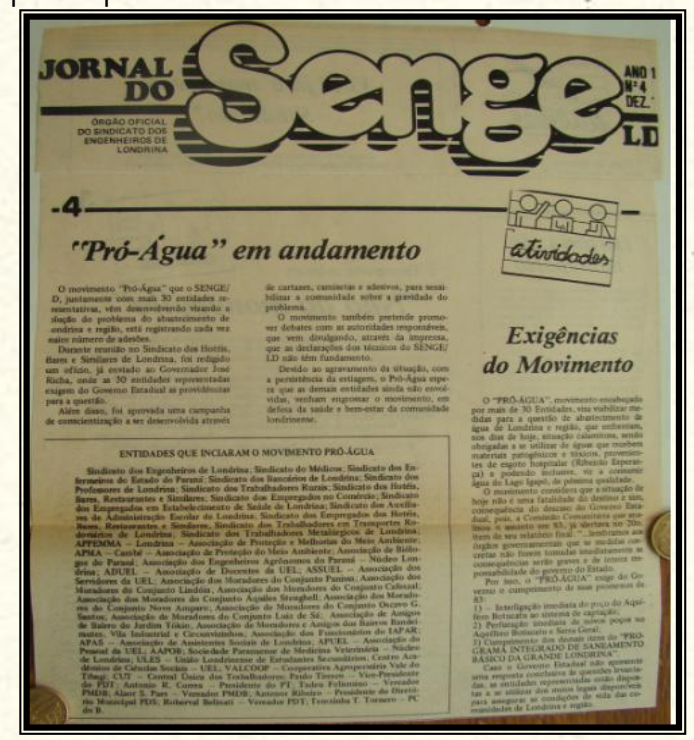

Imagem 4 - "Pró-Água" em andamento". Jornal do Sindicato dos Engenheiros de Londrina 4, dez. 1985, 1. Acervo: Centro de Documentação e Pesquisa Histórica - CDPH - Departamento de História/Universidade Estadual de Londrina. Foto: Gilmar Arruda.

\footnotetext{
73 "Previsão é de 20 anos para recuperação do rio Tibagi". Folha de Londrina, 18 jun. 1983, 7.

${ }^{74}$ Amanthea, 2004.

${ }^{75}$ Cito algumas das entidades que iniciaram o movimento Pró-Água: Sindicato dos Engenheiros de Londrina; Sindicato dos Médicos; Sindicato dos Enfermeiros do Estado do Paraná; Sindicato dos Bancários de Londrina; Sindicato dos Professores de Londrina; Sindicato dos Trabalhadores Rurais; Sindicato dos Hotéis, Bares, Restaurante e Similares; Sindicato dos Empregados do Comércio; APPEMA - Associação de Proteção e Melhoria do Meio Ambiente de Londrina; ADUEL - Associação de docentes da UEL e outros. A lista completa de entidades foi publicada pelo Jornal oficial dos Sindicatos dos Engenheiros de Londrina. "Pró-água em andamento". Jornal do Senge, Londrina, ano 1 número 4 dezembro, p.1.

${ }^{76}$ Amathea, 2004.
} 
0 texto informava sobre os motivos que levaram à formação do movimento, bem como trazia o nome das entidades envolvidas e das atividades que seriam desenvolvidas para chamar a atenção da sociedade como, por exemplo, a elaboração de uma campanha com cartazes, camisetas e adesivos para sensibilizar a comunidade. Além disso, segundo Nelson Amanthea, um dos coordenadores, o movimento buscou reforçar a imagem do rio Tibagi como poluído, como estratégia para seu fortalecimento:

0 Pró-Água teve desdobramento, a gente fez palestras, saímos na imprensa todo dia com novidade, aí vem à questão da paisagem do medo como estratégia consciente. Eu particularmente, como fui um dos coordenadores do movimento, segurei o tempo todo as entidades, a pressão era muito forte, no sentido de criar terror, um pânico na população sem ter alternativa. Nós não poderíamos sair aterrorizando a população, sem fundamentos fortes. Nós tínhamos elementos, mas não tínhamos prova cabal documentada. Aí nós tomamos conhecimento do material impresso pela SURHEMA em 1985 que mostrava a presença de venenos organoclorados em todos os rios do Paraná, inclusive na água tratada, e também no Tibagi. ${ }^{77}$

Nota-se que, inicialmente, Nelson Amanthea não concordava com a estratégia de utilização do medo da poluição, 0 que poderia aterrorizar ainda mais a população com as consequências da ingestão das águas do Tibagi. Porém, após ter acesso aos dados oficiais da pesquisa realizada pela SURHEMA, o engenheiro concordou com incorporação e ampliação da imagem do rio Tibagi como poluído, uma vez que os resultados comprovavam a presença dos agrotóxicos e outros venenos no rio. ${ }^{78}$ Uma das formas utilizadas pelo movimento Pró-Água para ampliar a circulação da percepção do rio Tibagi como poluído foi a criação de logotipos, como podemos observar abaixo:
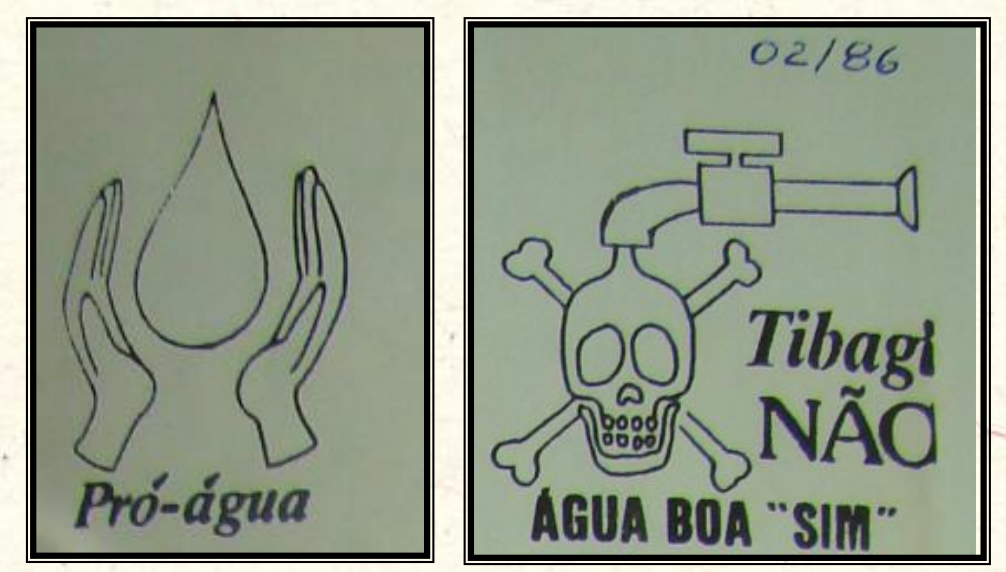

Imagem 5 - "Pró-Água" avança”. Jornal do Sindicato dos Engenheiros de Londrina 5, março de 1986, 1. Acervo: Centro de Documentação e Pesquisa Histórica - CDPH - Departamento de História/Universidade Estadual de Londrina. Foto: Gilmar Arruda.

Os logotipos apareciam nos panfletos, nos jornais de algumas entidades e nos documentos produzidos pelo movimento. As suas mensagens eram simples e diretas. A imagem da esquerda que tem o desenho de uma gota d'água protegida pelas mãos é o símbolo que o movimento escolheu para representar as boas intenções do movimento. Junto a essa figura era colocado o outro logotipo que representava as águas poluídas do Tibagi, a gota d'água na forma de caveira saindo da torneira mostra claramente a visão que os participantes do movimento tinham sobre 0 rio, um grande manancial de veneno. Porém, no ano seguinte ao seu surgimento, em 19860 movimento se encerrou. Segundo Amanthea os principais fatores foram à ausência de recursos, do trabalho

\footnotetext{
${ }^{77}$ Amathea, Entrevista..., 2009
}

${ }^{78}$ Amathea, Entrevista..., 2009. 
voluntariado e a dificuldade de ficar o tempo todo envolvido com a questão da água.79 Um ano após 0 encerramento do movimento as obras do Projeto Tibagi recomeçaram, tendo sido o complexo inaugurado oficialmente em dezembro de 1991 pelo Governo de Roberto Requião.

\section{Conclusão}

0 rio Tibagi, corre na divisa do município de Londrina e Jataizinho, cerca de $30 \mathrm{~km}$ a leste do centro urbano. Até 0 início dos anos de 1970 eram encontradas poucas referências no noticiário da cidade. Algumas reportagens sobre o seu nível em épocas de secas; alguns acidentes com pescadores, ou de motoristas ao atravessar a ponte em Jataizinho. Poder-se-ia afirmar que, até então, o rio era para os Iondrinenses só ' paisagem'. Entretanto, como procuramos demonstrar no texto, a partir do momento no qual as autoridades projetaram captar suas águas para 0 abastecimento dos habitantes ele se tornou presente no cotidiano dos moradores. Sua entrada para o primeiro plano da cena das relações entre os humanos e a natureza se deu pela dependência insuperável dos humanos com o mundo natural, neste caso, a necessidade de água para sobrevivência. Ele apareceu em cena, trajando os adereços nos novos tempos da era da ecologiả representando, para muitos, o personagem da poluição ameaçando os humanos, para outros, o personagem da salvação, 0 da água abundante que iria resolver a falta d'agua da cidade. Nesse texto, procuramos jogar luz em como se deu a construção do personagem ameaçador; quais adereços; quais cores e falas; quais interlocutores ecoavam essa 'paisagem do medo'. Não importou, para os nossos objetivos aqui, se o rio estava ou não poluído de fato, de acordo com os parâmetros daquele momento. Concretamente, o personagem ameaçador tomou a cena e desfilou ao longo dos anos de 1980, com o cortejo dos jornalistas, ambientalistas e sindicalistas, com parte da população amedrontada, jogando pedras e vaiando para que ele voltasse para os bastidores. Mas, para a maior parte da população, que sofria com a falta de água no cotidiano, suas águas eram mais importantes do que as ameaças da ' paisagem do medo' da poluição invisível.

Em um curto período, duas décadas, as representações existentes sobre o rio mudaram, resultantes de necessidades e medos do mundo natural e da degradação provocada pelos próprios humanos. Os movimentos de oposição não conseguiram impedir a captação das águas do rio Tibagi para 0 abastecimento de água de Londrina, mas suas ações e estratégias contribuíram para o surgimento do personagem ameaçador do rio poluído. Porém, no início dos anos de 1990, os cientistas da Universidade Estadual de Londrina e uma nova geração de ambientalistas, envolveram-se com o personagem, reescrevendo suas falas e dando-lhe outros adereços. Os projetos, pesquisas e publicações, tornaram-se, em parte, roteiros da atuação de um novo ambientalismo no final do século XX e primeira década do século XXI, transformando o rio como lugar de uma 'megabiodiversidade', uma estratégia para impedir o barramento por hidrelétricas. Mas esse é um outro ato dessa peça interminável encenada pelos humanos e a natureza.

${ }^{79}$ Amathea, Entrevista.., 2009. 